\title{
Stent-Jail Technique in Endovascular Treatment of Wide-Necked Aneurysm
}

\author{
Geniş Boyunlu Anevrizmanın Endovasküler Tedavisinde \\ Stent-JailTekniği
}

\author{
Qu RONG-BO ${ }^{1}$, Jin $\mathrm{HUA}^{2}$, Wang $\mathrm{KAI}^{3}$, Sun $\mathrm{ZE}-\mathrm{LIN}^{4}$ \\ ${ }_{1}^{1}$ Yantai Affiliated Hospital, Binzhou Medical University, Department of Neurosurgery, Nanhua Road, 264100, Yantai, Shandong, China \\ 2The Third Affiliated Hospital of Harbin Medical University, Department of Neurosurgery, Heping Road 158, 150040, Harbin, Heilongjiang, \\ P.R. China \\ ${ }^{3}$ Wendeng Center Hospital of Wei Hai, The Affiliated Hospital Weifang Medical College, Department of Neurosurgery, Weihai, Shandong, \\ 264400, P.R. China \\ ${ }^{4}$ Hebei United University Affiliated Hospital, Department of Neurosurgery, 57 JianSheNan Road, Tangshan, HeBei province 063000, P.R. \\ China
}

Correspondence address: Ze-lin SUN / E-mail: tsszl6@yahoo.com.cn

\begin{abstract}
AIM: To describe a reconstructive technique using single stent for wide-necked aneurysms.

MATERIAL and METHODS: This technique was described as stent-jail technique consisting of the aneurismal catheterization before the deployment of a self-expandable stent across the aneurysm neck. Following the deployment of the stent, embolization coils were delivered with the microcatheter positioned within the aneurysm dome and wedged between the stent and the aneurysm dome. The microstents, such as Neuroform, Leo and Wingspan stents, were used in in our series for electively treated aneurysms.

RESULTS: During a 3-year period,13 patients with wide-necked aneurysms were treated electively with this technique. The aneurysms arose from the internal carotid artery (5), anterior cerebral artery (4), anterior communicating artery (1), vertebral artery ( 1), middle cerebral artery (1) and middle cerebral artery (1). Thirteen stents (6 Leo stents, 4 Neuroform stents and 3 Wingspan stents) were successfully deployed across the aneurysm neck to constrain subsequent embolization coils of a wide-necked cerebral aneurysm. None of the patients experienced any periprocedural or delayed neurological complications. This maneuver enabled us to support the coil loops within the aneurismal sac with stabilization of the microcatheter.

CONCLUSION: The stent-jail technique represents an efficacious adjuvant technique to assist coiling of selected wide-necked cerebral aneurysms. This technique is particularly helpful for wide-necked aneurysms.
\end{abstract}

KEYWORDS: Aneurysm, Stent, Endovascular

öz

AMAÇ: Geniş boyunlu anevrizmalarda tek stent kullanarak rekonstrüktif bir tekniği tanımlamak.

YÖNTEM ve GEREÇLER: Bu teknik anevrizma boynu içinde kendiliğinden genişleyen bir stentin yerine yerleştirilmesinden önce anevrizmal kateterizasyondan oluşan stent-jail tekniği olarak tanımlanmıştır. Stent yerine yerleştirilmesinden sonra anevrizma kubbesi içinde konumlandırılan mikrokateterle embolizasyon sarmalları iletilmiş ve stent ile anevrizma kubbesi arasına kama şeklinde sokulmuştur. Neuroform, Leo ve Wingspan stentleri gibi mikrostentler serimizde elektif olarak tedavi edilen anevrizmalar için kullanılmışlardır.

BULGULAR: 3 yıllık bir dönemde bu teknik ile geniş boyunlu anevrizması olan 13 hasta elektif olarak tedavi edilmiştir. Anevrizmaların kökeni internal karotid arter (5), anterior serebral arter (4), anterior kommunikan arter (1), vertebral arter (1), orta serebral arter (1) ve orta serebral arter (1) olmuştur. On üç stent (6 Leo stenti, 4 Neuroform stent ve 3 Wingspan stenti) geniş boyunlu serebral anevrizmada daha sonraki embolizasyon sarmallarını sınırlandırmak üzere anevrizma boynu içinde başarılı şekilde yerine yerleştirilmiştir. Hastaların hiçbiri işlem sırasında veya gecikmiş nörolojik komplikasyon yaşamamıştır. Bu manevra sarmal halkalarını mikrokateter stabilizasyonuyla anevrizma kesesi içinde desteklememizi mümkün kılmıştır.

SONUÇ: Stent-jail tekniği seçilen geniş boyunlu serebral anevrizmalarda sarmal konmasına yardımcı olmak üzere etkin bir yardımcı tekniktir. Bu teknik özellikle geniş boyunlu anevrizmalarda faydalıdır.

ANAHTAR SÖZCÜKLER: Anevrizma, Stent, Endovasküler 


\section{INTRODUCTION}

Wide-necked aneurysms have been considered to be challenging to treat with endovascular approaches. Various adjunctive techniques, such as remodeling balloon and self-expandable microstents have been used to assist coil embolization of these lesions $(1,2,4,5,10-12)$. The microstents can be deployed prior to coil placement with the microcatheter delivered through the stent struts; after the deployment of a first coil without detachment, named the stent-jack technique; alone without coil placement; or following coil occlusion performed with balloon remodeling $(1,6,7,13,14)$.

In this study, we present our experience with 13 patients in which a self-expandable stent was placed prior to coil placement, with the microcatheter positioned within the aneurysm dome and wedged between the stent and the vessel wall, which has been called "stent-jail technique" $(1,4)$.

\section{PATIENTS and METHODS}

Between January of 2006 and January of 2009, 107 aneurysms were treated endovascularly at our institutions with the microstents. Throughout the study period, 13 patients with 13 aneurysms (12.1\%) were treated with the stent-jail techque endovascularly. These 13 patients were reviewed retrospectively. The mean age of the patients was 44.3 years (range, 22- 62 years). Eight of the 13 patients presented with subarachnoid hemorrhage $(\mathrm{SAH}), 3$ patients had incidental aneurysms, 1 patient presented with a complex recanalization from a previously coiled aneurysm, 1 patient with vertebral artery aneurysm presented with dysarthria. Patient characteristics are shown in Table I.

Before embolization procedures, conventional angiography of both internal carotid arteries and vertebral arteries and three- dimensional angiography were performed for all patients. The stent-jail technique was performed when the anatomy or location of the aneurysm made stent struts catheterization or the stent-jack technique difficult, such as small parent vessel and small or shallow aneurismal sac.

\section{Technique description}

The stent-jail technique was used to treat 13 wide-necked aneurysms (12 saccular and 1 fusiform). It consisted of catheterization of the microcatheter using coil delivery first into the aneurismal sac and then positioning a selfexpandable stent (Neuroform3/ Wingspan, Boston Scientific, Fremont, CA; or Leo, Balt, Montmorency, France) across the aneurismal neck and releasing the stent before the first coil was introduced into the sac. The length of the microstent was at least $5-\mathrm{mm}$ landing zone $(5 \mathrm{~mm}$ beyond the aneurysm neck on either side). The size of the stent was 0.5 to $1.0 \mathrm{~mm}$ greater than the parent vessel at the targeted landing zone. Following delivery of the stent, subsequent coil embolization was performed to obliterate the lesion.

All embolization procedures were performed while under general anesthesia. After right femoral artery access was achieved, intravenous heparinization was initiated, consisting of a bolus of $4000 \mathrm{IU}$ of heparin and then an immediate infusion of $1000 \mathrm{IU} / \mathrm{h}$. A 6-French, $90 \mathrm{~cm}$ Envoy guiding catheter (Cordis Neurovascular, Miami Lakes, FL) was catheterized into the cervical segment of the parent vessel, which included the internal carotid artery (ICA) and vertebral artery (VA). Our technique for stent-assisted coil embolization of wide-necked aneurysm has been described in detail (8-11). In brief, patients without SAH were administered with $75 \mathrm{mg}$ of clopidogrel and $300 \mathrm{mg}$ of aspirin (Plavix; Bristol-Myers Squibb/Sanofi Pharmaceuticals, NY) for 3 days preceding stent placement and patients with $\mathrm{SAH}$ were pretreated with

Table I: Cerebral Aneurysms Treated with Stent-Jail Technique

\begin{tabular}{|c|c|c|c|c|c|c|c|c|c|}
\hline $\begin{array}{c}\text { Patient } \\
\text { N. }\end{array}$ & $\begin{array}{l}\text { Age } \\
\text { Sex }\end{array}$ & Presentation & Location & $\begin{array}{c}\text { Type/size } \\
\text { (mm) }\end{array}$ & $\begin{array}{c}\text { Neck size } \\
(\mathrm{mm})\end{array}$ & Stent & $\begin{array}{l}\text { Size } \\
(\mathrm{mm})\end{array}$ & $\begin{array}{c}\text { Follow-up } \\
\text { (months) }\end{array}$ & $\begin{array}{l}\text { Clinical } \\
\text { outcome }\end{array}$ \\
\hline 1 & $38 / F$ & $\mathrm{SAH}$ & Acom & Saccular/3 & 3 & Leo & $3 \times 20$ & 26 & Excellent \\
\hline 2 & $48 / / F$ & Incidental & supraclinoidal ICA & Saccular/5 & 5 & Leo & $4.5 \times 25$ & 20 & Excellent \\
\hline 3 & $41 / F$ & $\mathrm{SAH}$ & supraclinoidal ICA & Saccular/2.5 & 3.7 & Leo & $4.5 \times 20$ & 15 & Excellent \\
\hline 4 & $31 / F$ & SAH & supraclinoidal ICA & Saccular/3 & 4 & Leo & $4.5 \times 20$ & 18 & Excellent \\
\hline 5 & $62 / F$ & Recanalization & supraclinoidal ICA & Saccular/2 & 3 & Leo & $4.5 \times 25$ & 18 & Excellent \\
\hline 6 & $61 / F$ & Incidental & supraclinoidal ICA & Saccular/4.2 & 5 & Leo & $4.5 \times 20$ & 17 & Excellent \\
\hline 7 & $43 / \mathrm{M}$ & Dysarthria & VA & Fusiform/5 & 6 & Neuroform & $3.5 \times 20$ & 12 & Excellent \\
\hline 8 & $52 / F$ & Incidental & M2 & Saccular/3.4 & 4 & Neuroform & $3 \times 20$ & 7 & Excellent \\
\hline 9 & $22 / F$ & $\mathrm{SAH}$ & P1 & Saccular/2.5 & 3 & Neuroform & $2.5 \times 15$ & 11 & Excellent \\
\hline 10 & $41 / \mathrm{M}$ & SAH & $\mathrm{A} 1$ & Saccular/2 & 2 & Wingspan & $2.5 \times 9$ & 13 & Excellent \\
\hline 11 & $37 / F$ & $\mathrm{SAH}$ & $\mathrm{A} 1$ & Saccular/1.5 & 2 & Wingspan & $2.5 \times 9$ & 14 & Excellent \\
\hline 12 & $57 / M$ & SAH & $\mathrm{A} 1$ & Saccular/2 & 2 & Wingspan & $2.5 \times 9$ & 12 & Excellent \\
\hline 13 & $43 / \mathrm{M}$ & SAH & $\mathrm{A} 1$ & Saccular/2.5 & 3 & Neuroform & $3 \times 20$ & 9 & Excellent \\
\hline
\end{tabular}

M, male; F, femal; SAH, subarachnoid hemorrhage; ICA, internal carotid artery; Acom, anterior communicating artery; VA, vertebral artery. 
$300 \mathrm{mg}$ of clopidogrel 2 hours before procedure. Patients were given $100 \mathrm{mg}$ aspirin and $75 \mathrm{mg}$ of clopidogrel (Plavix; SanofiAventis, Paris, France) daily for 3 months after the procedure.

\section{RESULTS}

\section{Aneurysm and parent vessel characteristics}

All aneurysms featured wide necks. The mean aneurysm size was $3.0 \mathrm{~mm}$ (range, $1.5-5 \mathrm{~mm}$ ). The mean neck size of these aneurysms was $3.5 \mathrm{~mm}$ (range, 2-6 mm). Reasons for choosing coiling over surgical clipping were: two patients had posterior circulation aneurysms; one patient had an Acom aneurysm, 1 had a $M 2$ segment and 4 had $A 1$ segment aneurysms, chose endovascular treatment rather than clipping; and five patients had supraclinoidal ICA aneurysm.

\section{Aneurysm approaches}

Four Neuroform stents were deployed into the VA and A1 segment. Six Leo stents were positioned in the ICA and A1 segment. Three Wingspan stents were used in the A1 segment. In all cases, there was no difficulty in catheterization of the coiling catheter prior to the deployment of the stent. Embolization coils were easily delivered via the microcatheter within the aneurismal sac without any protrusion through the stent struts. All aneurysms were obliterated completely at one stage with patent parent vessel. No thromboembolic complications or stent migration occurred.

\section{Clinical and Angiographic Outcome}

All patients received clinical follow-up evaluations (range, 7-26 mo; mean, $14.8 \mathrm{mo}$ ), and no major adverse events were observed. Twelve of the13 patients also had follow-up angiograms (range, 3-8 mo; mean, $6.6 \mathrm{mo}$ ). There was no evidence of recanalization.

\section{ILLUSTRATIVE CASE}

\section{Patient 4}

A 31-year-old woman was admitted for endovascular embolization of an acutely ruptured small aneurysm (sac, 3 $\mathrm{mm}$; neck, $4 \mathrm{~mm}$ ) of the supraclinoidal segment of the left internal cerebral artery (Figure $1 \mathrm{~A}, \mathrm{~B}, \mathrm{C})$. After the navigation of an Echelon 10 microcatheter (M.T.I --ev3, Irvine, CA) into the aneurismal sac, a Leo stent $(4.5 \times 20 \mathrm{~mm})$ was placed across the aneurismal neck and to reconstruct the arterial wall. The coil embolization was introduced until the aneurismal sac was completely filled.

\section{DISCUSSION}

When the aneurismal sac was catheterized, the stent was deployed carefully across the aneurismal neck. Then, the sac was progressively coiled between the aneurysm dome and the stent struts, which served as a support to reconstruct the arterial wall. This manipulation is the source of the name stent-jail technique. This technique will improve the outcome of coiling wide-neck aneurysms, specifically small widenecked aneurysms, by avoiding the difficulties in navigation of the coil delivery microcatheter via the stent strut and adequately keep the coils in the aneurismal sac and stabilize the microcatheter. This is why we used stent jail technique only for 13 patients out of 107 patients. In most of cases with preferable aneurismal sac, we would deploy a microstent prior to coil placement with the microcatheter delivered through the stent struts or after the deployment of a first coil without detachment, named the stent-jack technique. In this study, we had used several different type of stents because these stents were introduced between 2006 and 2009 into China and there is no criterion that influenced choosing the stent. The self-expandable stent allows the constraining of

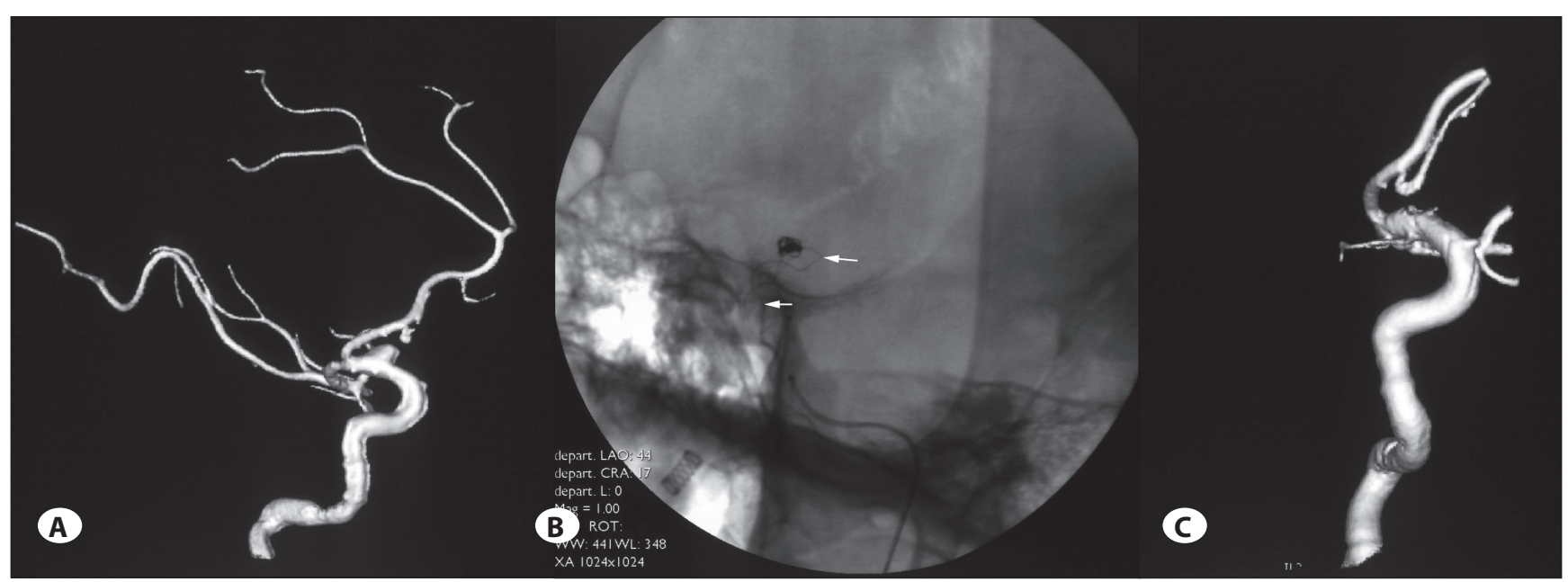

Figure 1: Patient 4. A 31-year-old woman with an acutely ruptured small aneurysm of the supraclinoidal segment of the left internal cerebral artery. A) Left internal carotid angiography, 3-D reconstruction, demonstrated a $3 \mathrm{~mm}$ supraclinoidal aneurysm with a $4 \mathrm{~mm}$ wide neck. Moreover, the acute angulation of the cavernous segment of the ICA with respect to the supraclinoid ICA likely would cause difficulty in catheterization of the stent struts and a coil could not be positioned in the aneurismal sac. It was decided to use the stentjail technique. A $4.5 \times 20 \mathrm{~mm}$ Leo stent was delivered after aneurismal catheterization. B) Fluoroscopic image reveals the Leo stent in position across the aneurysm neck (arrows). C) The coil embolization was introduced until filling of the sac was completed. 
possible coil protrusion by pushing the coil loop back into the aneurismal sac or by pinning it against the arterial wall. In aneurysms with dome-to-neck ratios smaller than 1.0, the first coil cannot be positioned into the sac (the coil loop will protrude into the arterial lumen completely), with the aim of coil delivery being to form the most homogeneous framing of the aneurysm sac. Before coil delivery, the stent was carefully positioned across the neck. This technique was particularly suitable for the treatment of small, acutely ruptured widenecked aneurysms (15).

The stent-jail technique does improve the results of stent assisted coiling, more specifically for small wide-neck aneurysms or aneurysms with a dome-to-neck ratio smaller than 1.0 as in our patients. There is often a higher likelihood of rupturing of the small wide-neck aneurysm because of the difficulty associated with passing the catheter through the stent strut when these aneurysms are treated through the original paradigm of first placing a stent and then catheterizing the aneurysm sac through the stent struts. This stent-jail technique obviates this risk by first navigating the microcatheter in place. Nonetheless, this technique does not guarantee that the coil will not continue to protrude through the struts of the stent, especially when small-diameter coils are used.

There are also some limitations for this study, such as lack of long term follow-up, and the fact that it is a retrospective study of a single center. On the other hand, navigating the coil delivery microcatheter before stent positioning has some drawbacks. First, the jailed microcatheter technique does not offer the possibility of modifying the microcatheter position within the aneurysm sac, resulting in many instances in incomplete aneurysm packing with coils. Second, when the stent is deployed before coil delivery, the operator should be very cautious while coiling the aneurysm through the microcatheter to prevent aneurismal rupture caused by coil impingement on the aneurismal dome. The coil diameter should be selected smaller than the aneurismal dome.

\section{CONCLUSION}

The stent-jail technique represents a useful adjuvant technique to assist the coiling of selected wide-necked cerebral aneurysms.

\section{ACKNOWLEDGEMENT}

Qu Rong-Bo and Jin Hua are equal first authors.

\section{REFERENCES}

1. de Paula Lucas C, Piotin M, Spelle L, Moret J: Stent-jack technique in stent-assisted coiling of wide-neck aneurysms. Neurosurgery 62(ONS Suppl2): ONS414-ONS417, 2008

2. Hong B, Patel NV, Gounis MJ, DeLeo MJ 3rd, Linfante I, WojakJC, Wakhloo AK: Semi-jailing technique for coil embolization of complex, wide-necked intracranial aneurysms. Neurosurgery 65(6):1131-1139, 2009
3. Huang Q, Xu Y, Hong B, Zhao R, Zhao M, Liu J: Stent-assisted embolization of wide-neck anterior communicating artery aneurysms: Review of 21 consecutive cases. AJNR Am J Neuroradiol 30:1502-1506, 2009

4. Katz JM, Gobin YP, Riina HA: Interventional neuroradiology: Techniques and Devices in Interventional Neuroradiology. New York: Informa Healthcare USA, 2008:161-182

5. Kelly ME, Turner R, Gonugunta V, Woo HH, Rasmussen PA, Masaryk TJ, Fiorella D: Stent reconstruction of wide-necked aneurysms across the circle of Willis. Neurosurgery 61 ONS Suppl 2:ONS249-ONS255, 2007

6. Kis B, Weber W, Berlit P, Kühne D: Elective treatment of saccular and broad-necked intracranial aneurysms using a closedcell nitinol stent (Leo). Neurosurgery 58:443-450, 2006

7. Lubicz B, Francois $O$, Levivier $M$, Brotchi J, Balériaux D: Preliminary experience with the enterprise stent for endovascular treatment of complex intracranial aneurysms: Potential advantages and limiting characteristics. Neurosurgery 62: 1063-1070, 2008

8. Lv M, Lv X, Li Y, Jiang C, Jiang P, Wu Z: Dissecting aneurysm at proximal anterior cerebral artery treated by parent artery occlusion. Interv Neuroradiol 15:123-126, 2009

9. Lv M, Lv X, Li Y, Yang X, Wu Z: Vertebral dissecting aneurysm treated with the Wingspan stent deployment and detachable coils: Technical note. Interv Neuroradiol 15:113-116, 2009

10. Lv X, Jiang C, Li Y, Wu Z: Clinical outcomes of ruptured and unruptured vertebral artery-posterior inferior cerebellar artery complex dissecting aneurysms after endovascular embolization. AJNR Am J Neuroradiol 2010, Apr 15. Epub ahead of print

11. Lv X, Li Y, Jiang C, Yang X, Wu Z: Endovascular treatment using stents for vertebral artery fusiform aneurysms. Neurol Res 32: 792-795, 2010

12. Lylyk P, Miranda C, Ceratto R, Ferrario A, Scrivano E, Luna HR, Berez AL, Tran Q, Nelson PK, Fiorella D: Curative endovascular reconstruction of cerebral aneurysms with the pipeline embolization device: The Buenos aires experience. Neurosurgery 64:632-643, 2009

13. Mocco J, Snyder KV, Albuquerque FC, Bendok BR, Boulos AS, Carpenter JS, Fiorella DJ, Hoh BL, Howington JU, Jankowitz BT, Liebman KM, Rai AT, Rodriguez-Mercado R, Siddiqui AH, Veznedaroglu E, Hopkins N, Levy El: Treatment of intracranial aneurysms with the Enterprise stent: A multicenter registry. J Neurosurg 110:35-39, 2009

14. Wu Z, Lv X, Yang X, He H: Ruptured vertebro-inferoposterior cerebellar artery dissecting aneurysm treated with the Neuroform stent deployment and vertebral artery occlusion. Eur J Radiol Extra 70:e100-e103,2009

15. Zhang J, Lv X, Jiang C, Li Y, Yang X, Wu Z: Endovascular treatment of cerebral aneurysms with the use of stents in small cerebral vessels. Neurol Res 32(2):119-122, 2010 